\title{
IAMJ
}

INTERNATIONAL

AYURVEDIC

MEDICAL JOURNAL

Review Article

ISSN: 2320-5091

Impact Factor: 6.719

\section{THE STUDY OF AHAR MATRA W.S.R. TO JATHARAGNI AND ITS IMPORTANCE IN CASE HISTORY}

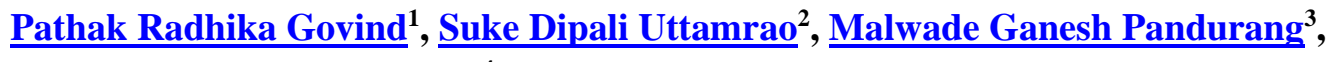
Surana Mayur Chandrakant $^{4}$

${ }^{1}$ Assistant Professor, Sanskrit Samhita Siddhant Dept, SSVP Ayurveda College and Research Center, Hatta, Maharashtra

${ }^{2}$ Assistant Professor, Sanskrit Samhita Siddhant Dept, Sai Ayurved College, Hospital and Research Center, Vairag, Maharashtra

${ }^{3}$ Assistant Professor, Shalya Tantra Department, LBVK Ayu Med. College. \& Hospital., Latur, Maharashtra ${ }^{4}$ MD (Kriya Sharir), DYA, PGDCR, Vardhayu Ayurved and Panchakarma Clinic, Nasik Road, Latur,

Maharashtra

Corresponding Author: drdipalisuke11@gmail.com

https://doi.org/10.46607/iamj09p5062021

(Published online: September 2021)

Open Access

(C) International Ayurvedic Medical Journal, India 2021

Article Received: 31/03/2021 - Peer Reviewed: 07/05/2021 - Accepted for Publication: 09/08/2021

Check for updates

\section{ABSTRACT}

In the present era, many diseases are occurring due to faulty dietary habits i.e. excessive or less diet intake. Considering these conditions, Matravat Ahar (proper quantity of diet) is important in the case history of particular Vyadhi (disease). Ayurved suggests taking matravat ahar. Ahar Matra (quantity of diet) depends on Jatharagni Bala, that's why it varies from person to person. Ahar Matra is of two types i.e. Samyak Matra (appropriate quantity) and Amatra (inappropriate), in which Amatra causes various diseases. Again, Amatra is of two types i.e. Heen Matra (deficient quantity) and Atimatra (excessive quantity). Heen Matra is the main cause of Vata Vikara (diseases of vata dosha) and Atimatra particularly causes Aampradoshaj Vikar (diseases due to aama). So detailed study of Ahar Matra is important while taking the case history of the patient. So that this attempt has been made to find out the concept of Samyak Ahar Matra explained in Ayurveda w.s.r. to Jatharagni (digestive fire) and its importance in the case history. 
Keywords: Matravat Ahar, Samyak Matra, Amatra, Heen Matra, Atimatra Jatharagni Bala, Aampradoshaj Vikar

\section{INTRODUCTION}

Nowadays there is an increased prevalence of lifestyle disorders. Faulty dietary habits (i.e. excessive or less intake of diet) play an important role in it. Ayurveda has given detailed guidelines regarding the proper quantity of food i.e. Ahar Matra. Ayurveda had described Ahar (diet), Nidra (sleep) and Brahmcharya (abstinence) as Trayopsthambha's (three sub pillars) ${ }^{[1]}$ which support the body itself. Here Ahar has been placed first which shows that it is most important to maintain and sustain life. But it is possible only when it is taken in proper quantity. Acharya suggested taking Matravat Ahar in each condition i.e. in Swastha (healthy) and Atur Avastha (diseased) ${ }^{[2]}$. Samyak Ahar Matra depends on Jatharagni Bala (power of digestion) of each person ${ }^{[2]}$. As Bala of Jatharagni varies from person to person, Ahar Matra also varies in the same. Ahar Matra is of two types i.e. Samyak Ahar Matra and Amatra, in which Samyak Ahar Matra is necessary to maintain health and Amatra causes several diseases. Again, Amatra is of two types- Heen Matra and Atimatra. Heen Matra causes vata vikar and Atimatra causes Tridosh Prakop (vitiation of tridosh) and Aampradoshaj Vikara ${ }^{[3]}$. So detailed study of Ahar Matra is also important while taking case history of the patient as Ahar Matra in itself is one of the reasons for many diseases, distress or discomfort. Considering these conditions, in the present study, the concept of Ahar Matra in Ayurveda w.s.r. to Jatharagni and its importance in case history is taken to highlight the concept of Samyak Matra, Amatra and diseases related to it.

\section{Concept of Aharmatra-}

Acharya Charak has suggested taking diet in proper quantity by particular Upadesh matrashee syat ${ }^{\prime[1]}$. That means we should take diet in proper quantity and that quantity of diet depends on Jatharagni Bala.

It is important to explain that how much quantity of diet is proper for a person. The quantity of diet taken by a person which digests in proper time $\&$ does not cause any disease is the proper quantity of diet for that person. The right amount of diet activates $A g n i^{[4]}$.
Ease of digestion should be understood according to the quantity of food either Guru or Laghu. Food particles that are light to digest (Laghu) eg. Shali (Oryza sativum), Shashtika (variety of oryza sativum), Mudga (Mung bean), Lava (common quail), Kapinjal (grey partridge), Harina (antelope), Sashaka (rabbit), Sharabha (wapiti), Shambar (Indian sambar deer) Mansa and those that are hard to digest (Guru) eg. Pishtavikruti (preparation of flour-pastry), Ikshuvikruti (products of sugarcane) and Ksheervikruti (products of milk) both require a specific quantity for proper digestion $^{[5]}$

The light food articles are predominant in qualities of Vayu \& Agni Mahabhoot whereas heavy food articles are in Prithvi \& Jala Mahabhoot ${ }^{[5]}$. Therefore, according to their quality, the light articles of food being stimulant of appetite by nature are considered to be less harmful even if taken in excess. On the other hand, heavy articles of food suppress appetite in all Rutu (season) except Hemant (pre-winter season) and unless there is a strong power of digestion achieved by Vyayam (exercise) ${ }^{[5]}$.

Thus, the quantity of food depends on the power of digestion.

The consumer of food should divide the total capacity of his Kukshi (stomach) into three parts. A third of the portion of the Kukshi should be allocated to solid food articles, a third to liquid food substances \& the remaining third should be left for movement for Vata, Pitta \& Kapha Doshas ${ }^{[3]}$.

One who abates by this basic thumb rule during dietary intake does not get affected by any adverse effect arising out of the improper amount of diet.

According to Acharya Vagbhat, two parts of Kukshi should be filled with solid foods, one part by liquids \& the remaining one part should be kept vacant for movement of Vata, Pitta and Kapha ${ }^{[6]}$.

Rashi (quantity) consists of Sarvagraha (account of whole amount or unit) \& Parigraha (account of part of substance) which ascertain the effect of any food article taken in proper or improper quantity ${ }^{[7]}$. 
Signs after consuming the proper amount of food [3]:

Any quantity of food to be consumed can be considered appropriate if-

- It does not exert undue pressure on the abdomen.

- It does not obstruct the proper function of the heart.

- It does not exert undue pressure on the sides of the chest.

- It does not leave a feeling of excessive heaviness in the abdomen.

- It properly nourishes the sense organs.

- It subsides hunger and thirst.

- After consuming, the person can perform activities such as standing, sitting, walking, exhaling, inhaling, laughing, and talking with ease.

- The food taken in the morning digested bye evening and vice versa.

- Food consumed in the appropriate quantity also enhances strength, complexion $\&$ the built of the body.

Signs and symptoms to decide proper digestion of food $^{[8]}$ -

Conditions in which,

- The Doshas do not get vitiated or unsettled from their natural locations.

- Agni is stimulated.

- Appetite is increased.

- Entrances of channels get cleared.

- Eructation is pure.

- Feeling of lightness and comfort at the level of the chest region.

- There are natural urges to pass bodily wastes like defecation or urination and there is no obstruction to their passage.

- And the food consumed enhances one's life without afflicting any Dhatu.

\section{Amatra (Inappropriate quantity of diet)}

Amatra is of two types Heen Matra i.e. deficient and Atimatra i.e. excessive.

The food taken in deficient quantity is said to be because of reduction in strength, complexion and nourishment of body tissues, non-satisfaction, altered peristalsis and mis displacement of Vayu, impairment of life functions, body tissues (Saara), sexual stamina (virility) and Ojas(vitality) damage to the body, mind, intellect and sense organs, inducing inauspiciousness and also making the person home to a variety of disorders of Vata $^{[3]}$.

One who eats solid food in excess \& also drinks beverages beyond satisfaction will have all the three Doshas-Vata, Pitta \& Kapha - in his stomach vitiated simultaneously due to their getting compressed by all the excess food. Thus, vitiated Doshas in the undigested food mass get localized into a part of the stomach, which then either obstructs the movement in the abdomen or suddenly gets eliminated through upper and lower channels of the alimentary tract. They produce distinct features in the person as follows ${ }^{[3]}$.

- Vata causes colic pain, distension of the abdomen, body ache, dryness of the mouth, fainting, giddiness, variability in the digestive power, rigidity in flanks, back and waist \& contraction (spasm) \& hardening of vessels.

- Pitta causes fever, diarrhoea, burning sensation inside the body, thirst intoxicated state, giddiness \& delirium and

- Kapha cause vomiting, anorexia, indigestion, fever with cold, laziness $\&$ heaviness in the body.

Food consumed in Atimatra causes Aampradoshaj Vikar like Alasak (sluggish bowels) \& Visuchika (noninfectious gastroenteritis) ${ }^{[9]}$.

Thus, it can be said that any wholesome food, even if taken in the right amount, does not get digested if the mental stage of the person is riddled with anxiety, grief, fever, anger or restlessness \& irritability due to lack of sleep.

As we discussed above, we can conclude that an improper quantity of diet leads to many diseases. In which deficient quantity of diet particularly leads to Vatavyadhi (diseases of Vata dosha) and excessive quantity vitiates all the Doshas and produces Aampradoshaj Vikar. That's why while taking the history of the patient, we should ask questions regarding the quantity of diet which should be useful to ascertain $\mathrm{Ni}$ dan (diagnosis) and Chikitsa (treatment).

\section{Questionnaire}

1. How many times do you consume food in a day?

2. Which type of solid food do you take in your

3. daily diet, and in how much quantity?

a) Jawar Roti b) Chapati c) Rice d) Vegetables 
4. Which type of liquid do you consume into your

5. daily diet \& how much quantity?

a) Water b) Butter-milk c) Milk d) Soup e) Curry

f) alcohol

6. Do you feel any undue pressure on your abdomen, after consuming food?

7. Do you feel palpitation or heaviness in the chest region?

8. Do you feel any pressure or pain on the side of the chest?

9. Do you feel excessive heaviness in the abdomen?

10. Does the quantity of food consumed subside your hunger \& thirst?

11. Do you able to perform activities such as standing, sitting, walking, inhaling, exhaling, Laughing, talking with ease?

12. Does the quantity of food take in the morning digest by evening with ease $\&$ vice-versa?

\section{DISCUSSION}

It is important to take diet in proper quantity and that quantity depends on Jatharagni bala ${ }^{[2]}$.

Modern science has particularly described Ahar according to the nutrition value of its components. But according to Ayurved Purusham Purusham Vikshya ${ }^{[10]}$ i.e. every person is different and unique and hence Jatharagni Bala i.e power of digestion of each person is important to decide the proper quantity of diet. The right amount of diet activates Agni \& it does not cause any disease ${ }^{[4]}$.

Digestion is affected by Gurutwa (heaviness) \& Laghutwa (lightness) of Ahar dravya. So, both Guru \& Laghu Ahar Dravyas require a specific quantity for proper digestion ${ }^{[5]}$.

Acharya Charak suggested dividing the total capacity of Kukshi (stomach) into three-part, while Acharya Vagbhat divided Kukshi into four parts ${ }^{[6]}$.

Charakacharya has described signs after consuming the proper amount of food by which we can assess the quantity of diet in the patient.

Timely defecation \& urination with ease particularly shows proper digestion. Ahar Matra is of two types Heen matra and Atimatra.

Heen Matra leads to Vatvikaras while Atimatra causes Tridosh Prakop \& Aampradoshaj Vikar. According to Acharya Chakrapani, Ahar Matra is the most important factor to maintain Swathaya ${ }^{[2]}$. That's why
Ahar Matra is important in the case of history for diagnosis of disease. Therefore, we formed the questionnaire which particularly depends on signs after consuming the proper amount of food. This questionnaire will be helpful to decide the proper quantity of food according to Jatharagni Bala.

\section{CONCLUSION}

With the above study, we can conclude that the role of Jatharagni is important to calculate Ahar Matra. Ahar Matra also depends on Gurutwa \& Laghutwa of Ahar Dravya. Division of Kukshi into three parts is necessary while taking diet. Inappropriate quantity of diet leads to many diseases, that's why detailed history about the quantity of diet is important in the case history.

\section{REFERENCES}

1. Vaidya Yadavaji Trikamji Acharya, Charak Samhita, Chakrapani Tika, Reprint 2013 p.74

2. Vaidya Yadavaji Trikamji Acharya, Charak Samhita, Chakrapani Tika, Reprint 2013 p.36

3. Vaidya Yadavaji Trikamji Acharya, Charak Samhita, Chakrapani Tika, Reprint 2013 p.238

4. Vaidya Kaviraj Atridev Gupta, Ashtangahrudayam, Reprint 2009 p.97

5. Vaidya Yadavaji Trikamji Acharya, Charak Samhita, Chakrapani Tika, Reprint 2013 p.37

6. Vaidya Kaviraj Atridev Gupta, Ashtangahrudayam, Reprint 2013 p.103

7. Vaidya Yadavaji Trikamji Acharya, Charak Samhita, Chakrapani Tika, Reprint 2013 p.236

8. Vaidya Yadavaji Trikamji Acharya, Charak Samhita, Chakrapani Tika, Reprint 2013 p.237

9. Vaidya Yadavaji Trikamji Acharya, Charak Samhita, Chakrapani Tika, Reprint 2013 p.239

10. Vaidya Yadavaji Trikamji Acharya, Charak Samhita, Chakrapani Tika, Reprint 2013 p.22

\section{Source of Support: Nil}

\section{Conflict of Interest: None Declared}

How to cite this URL: Suke Dipali Uttamrao et al: The Study Of Ahar Matra W.S.R. To Jatharagni And Its Importance In Case History. International Ayurvedic Medical Journal \{online\} 2021 \{cited September, 2021\} Available from: http://www.iamj.in/posts/images/upload/3109 3112.pdf 